THE INTERNATIONAL

JOIJRNAL

Of Environmental, Cultural,

Economic \& Social

SUSTAINABILITY

Volume 7 , Number 1

Collaborative Partnership for Education for Sustainability: New Zealand Vocational Education

Rashika Sharma 
THE INTERNATIONAL JOURNAL OF ENVIRONMENTAL, CULTURAL, ECONOMIC AND SOCIAL SUSTAINABILITY

http://www.Sustainability-Journal.com

First published in 2011 in Champaign, Illinois, USA

by Common Ground Publishing LLC

www.CommonGroundPublishing.com

ISSN: $1832-2077$

(C) 2011 (individual papers), the author(s)

(c) 2011 (selection and editorial matter) Common Ground

All rights reserved. Apart from fair dealing for the purposes of study, research, criticism or review as permitted under the applicable copyright legislation, no part of this work may be reproduced by any process without written permission from the publisher. For permissions and other inquiries, please contact

<cg-support@commongroundpublishing.com>.

THE INTERNATIONAL JOURNAL OF ENVIRONMENTAL, CULTURAL, ECONOMIC AND SOCIAL SUSTAINABILITY is peer-reviewed, supported by rigorous processes of criterion-referenced article ranking and qualitative commentary, ensuring that only intellectual work of the greatest substance and highest significance is published.

Typeset in Common Ground Markup Language using CGPublisher multichannel typesetting system

http://www.commongroundpublishing.com/software/ 


\title{
Collaborative Partnership for Education for Sustainability: New Zealand Vocational Education
}

\author{
Rashika Sharma, UNITEC Institute of Technology, New Zealand
}

\begin{abstract}
This year marks the midpoint of the Decade of Education for Sustainable Development but sustainability still remains a foreign concept in the New Zealand vocational and trade education curriculum. Thus research was conducted to gauge the existing perceptions of academics and industry and discover the reasons for the slow embedding of sustainability concepts in the curriculum. The research followed a qualitative research methodology using a case study as the method of inquiry which collected data through 8 in-depth interviews conducted with academics and industry personnel at a New Zealand vocational institute. The research found that there was no collaboration between academics and industry when it came to education for sustainability (EfS) with neither group taking responsibility for embedding the concepts into the curriculum. The overall awareness level on sustainability was very low between the two researched groups. Academics and Industry personnel alike saw no relevance of sustainability in vocational trade education. The slow progress of embedding sustainability concepts into the vocational education curriculum could be a result of this lack of collaboration between these two groups thus it is recommended that a professional development course be designed for vocational academics and industry personnel to increase awareness on sustainability concepts.
\end{abstract}

Keywords: Education for Sustainability, Vocational Education, Sustainability Concepts, Emdedding into Curriculum

\section{Introduction}

DHE UNITED NATIONS (2004) has declared a Decade of Education for Sustainable Development from 2005-2014. The decade of education was declared in the hope that all levels of education and all learning institutes around the world would work towards educating the population at large about sustainability (Parliamentary Commission for the Environment (PCE), 2004). The year 2010 marks the midpoint of this decade of education and still the concept of sustainability remains vague and non-existent from many educational programmes in New Zealand (Stone and Baldoni, 2006). For the purposes of discussions in this paper, sustainability is focusing on the environmental dimensions and ensuring all practices in society consider reducing the negative impacts on the environment. Sustainability education is defined by Moore (2005) as "education that concentrates on the concept of sustainability in a manner that fits with the values of sustainability" (p. 78) Schianetz, Kavanagh and Lockington (2007) define a concept as an idea of how to achieve sustainability. Srinivas (n.d.) defines concepts as strategies, tools, ideas and models that can be used to achieve sustainability.

The International Journal of Environmental, Cultural, Economic and Social Sustainability Volume 7, Number 1, 2011, http://www.Sustainability-Journal.com, ISSN 1832-2077 


\section{Scope for EfS in Vocational Education}

The New Zealand Parliamentary Commissioner recognises the importance of education for sustainability (EfS) but not enough has been done in many educational sectors to incorporate sustainability concepts into the curriculum. Eventhough research indicates that more New Zealanders have certificate level qualification compared to degree qualifications (Parliamentary Commission for the Environment (PCE), 2004) sustainability concepts are still focused only on degree programmes and remain absent in vocational trade education.

Vocational courses have the highest number of enrolments but it is astonishing to see that all universities and many polytechnics and institutes of technology in New Zealand have overlooked the incorporation of sustainability concepts into vocational level curriculum. Only 30\% of New Zealand polytechnics and institutes of technology offer sustainability programmes (Stone \& Baldoni, 2006). This suggests that sustainability may not be covered to a great extent at vocational training level.

Sterling (2001) outlined that the achievement of economic prosperity still dominates the education sector. The vocational education and trades sector appears to predominantly prepare students mainly for economic life and ways of meeting material needs. In such an environment the scope for implementing other areas of focus, such as sustainability, becomes secondary. The establishment of sustainability in the workplace culture requires vocational and trades to evolve and embrace globalisation and technological change and meet the needs of the workforce culture (UNDESA, 1992). Fein and Wilson (2005) say that vocational and trades education has the potential to foster change in the workplace but can only be achieved through a revision of institutions and curriculum. Vocational and trades has the opportunity to address workforce needs, incorporate sustainability principles into teaching and learning (Mazzotti, Murphy \& Kent, 2007).

Two of the main key players of vocational trade education are academics and industry. The following section addresses the influence these two groups have on the vocational curriculum.

\section{Influence of Academia on Sustainability Curricula in Higher Education}

Thomas (2004) suggests that one of the reasons sustainability education is slow in being incorporated in tertiary curriculum is because academics have limited knowledge of the issue and fail to understand why their engagement with sustainability education is important. According to Reid and Petocz (2006) many academics from other disciplines do not even understand sustainability jargon and do not see the relevance of it in their subjects. Many academics are reluctant in teaching something beyond their subject knowledge (Down, 2006).

Thomas and Nicita (2002) say academics are "busy people and already have many calls on their time" (p. 488). Teachers and academics need all the relevant material and necessary support to teach sustainability especially if the subject is a new concept for him or her. This point has been researched as well by Reid and Petocz (2006) who tried to determine university lecturers understanding of sustainability. The academics were asked about their conceptions about sustainability and how they could embed the topic into their subjects. Majority of the academics stated that sustainability and their subject was total separate entities and many had no idea of the common sustainability jargons. Reid and Petocz (2006) suggested that in order to incorporate sustainability in all subjects at university level "it would seem necessary 
to tackle the ways in which academics themselves - the teachers- understand the issue of sustainability" (p. 121).

According to Down (2006) another challenge for incorporating sustainability into syllabus is how to deal with aspects that are outside the lecturers' area of expertise. If lecturers are responsible for teaching sustainability concepts then in addition to their own subject matters they also need to be abreast with these issues. Thomas and Nicita (2002) recommend that a clearer and easily understood concept of sustainability needs to be developed that academics can readily grasp and apply to their teaching. Down (2006) also discovered through the research that one of the challenges of incorporating sustainability into the curricula is to get staff involved in reorienting their course/programme to address sustainability. This showed that motivating educators to understand and accept the principles of sustainability is the key factor in sustainability implementation in the curricula.

\section{Industry Influence on Sustainability Curricula in Higher Education}

The industry or employment sector plays a critical role in the embedding of sustainability education in tertiary institutes. The industry sector is a key player when determining the curricula and making decisions on what goes in the course content for any subject. Wright (2003) states that the time for incorporating sustainability into the architecture curriculum in the United States arrived when five collateral organisations that influence architectural education identified it as a core issue of architecture. Before that time sustainability's incorporation into curriculum was not a priority. In other words industry plays a key role in dictating what is included in the curricula. Since no such information was found in the literature regarding sustainability education incorporation at trade level this research will contribute to understanding the trade industry's perceptions on sustainability.

These skills need to be embedded in industry related courses so that education providers can respond to immediate market needs (Ministry of Education, 2005). This viewpoint is also expressed by Wright (2003) who identified sustainability as an initiative that can be implemented into education if it is supported by industry. It seems that sustainability has not yet been identified as a "market need" by industries in New Zealand which probably is the main reason it has been so slow in being implemented at vocational studies.

As emphasised in the previous sections the sustainability content implementation in the curriculum is very slow as a result of various factors and challenges. These challenges apply to all tertiary education institutes all over the world however so far the emphasis has been on universities with the vocational and training institutes been extremely neglected. It is apparent that many do not see the need or relevance for incorporation of sustainability education in the trades industry but it should not be overlooked that the vocational level provides important skills for the workplace.

Therefore it was necessary to investigate the reasons for the slow embedding of sustainability concepts in the New Zealand vocational curriculum. In order for this to be achieved the two main stakeholders of vocational studies were consulted to obtain their perceptions on the topic of sustainability. This research gives valuable insight into the vocational education system and highlights some of the factors that are responsible for the slow implementation for education for sustainability. It should be noted that students also comprised a significant part in this research but for the purposes of this paper their feedback has not been included. 


\section{Research Objectives}

The purpose of this qualitative research was to determine the current perceptions for incorporating sustainability concepts into vocational and trade education in New Zealand.

The research included addressing the following aims:

- Determine the perceptions the trade industry personnel have about incorporating sustainability concepts into the $\mathrm{NZ}$ vocational and trade education.

- Investigate the perceptions academics have about incorporating sustainability concepts into $\mathrm{NZ}$ vocational and trade education.

\section{Methodology}

This research aimed to gain insights, thoughts and opinions on the incorporation of sustainability concepts at vocational trade education in New Zealand. Qualitative research according to Creswell (2007) should be used when a complex, detailed understanding of an issue is needed and this detail can only be established by directly talking to people and empowering them to share their stories. Thus the research conducted followed a qualitative perspective in order to achieve its research objective and gather meaningful data because quantitative measures and the statistical analyses simply did not fit the problem (Creswell, 2007).

A case study is generally useful in making comparisons or drawing similarities between analogous education institutions (Johnson, 2007). In this research the case may be used to make generalisations of what other vocational institutes in New Zealand experience. A case study appeared appropriate for the research therefore a single case was selected as it was sufficient to fulfil all the conditions of the research objective. The scope and timeline for the project also limited data collection and thus investigating more than one institute was impossible. This research was focused on obtaining the perceptions of stakeholders on the incorporation of sustainability education in vocational and trade studies in New Zealand therefore it would have been beyond the capacity of this research to evaluate what all vocational institutes experience. As case studies can be generalisations and applied in many contexts, focusing on a single institute would have generated many similarities and differences that could be applicable in many educational institutions in New Zealand.

\section{The Research Process}

The Case: For the purposes of this research an institute was to be selected that offered vocational and trade education certificate and degree programmes. Hence a New Zealand metropolitan technical institute was chosen that offered a wide range of industry-related education and training programmes designed for tradespeople and technologists in the fields of Automotive Engineering, Carpentry, Electro Technology, Furniture and Joinery, Interior Décor, Plumbing \& Gasfitting, Welding and Fabrication, Boat Building and Marine Engineering. Upon a review of the programme descriptors no mention of sustainability concepts were found in any of the above mentioned disciplines.

Data Collection Methods: Interviews provide data that can describe exactly how the informant feels, perceives and how they behave (Burns, 1994) and to sample respondents' opinions (Cohen, Manion \& Morrison, 2001). Since perceptions and opinions are most easily obtained through face to face interviews, this became the main method of data collection for the re- 
search. Standardised open-ended interviews are pre-planned with exact wording and questions determined in advance. All interviewees are asked the same questions and in the same order which increases comparability of responses and organisation and analysis of data is fairly simple. The later option seemed ideal for this interview as data between respondents could be easily compared with generalisations and themes easily drawn between responses. However "standardised wording of questions may constrain and limit naturalness and relevance of questions and answers" (Cohen, Manion \& Morrison, 2007, p. 271) but a standardised interview was more suited for this research due to the potential of data comparability. All the categories of interviewees (industry personnel and academics) thus participated in an hour long standardised open ended interview and answered the same questions as this increased comparability of responses and ensured uniformity in questions asked and ease of data analysis.

Participants \& Sampling: The academics recruited for this study were programme coordinators from Automotive Engineering, Building Technology, Electrotechnology, and Marine Technology since only these disciplines offered both certificate and degree programmes. Therefore $\mathbf{4}$ interviews with programme coordinators were conducted. To maintain consistency in the selection process, the industry personnel and academics represented the same disciplines mentioned above. Thus a total of $\mathbf{4}$ industry personnel interviews were conducted. In total 8 in-depth interviews were conducted.

Data Analysis Methods : The entire interview data collected was first transcribed and then analysed through a process of thematic analysis. Thematic analysis is identification of themes through a process of careful reading and re-reading of the data. It is a form of pattern recognition within the data, where emerging themes become the categories for analysis (Fereday and Muir-Cochrane, 2006). The interview was then analysed using Somerville's (2003) thematic analysis where ideas within transcripts are arranged in a numerical order or coded. Each new idea within the transcript was given a number/code. After the numerical order was designated to the whole transcript, the similar ideas were clustered together into themes for further discussion.

\section{Findings \& Discussion: Barriers to Education for Sustainability in Vocational Trade Education}

A number of themes emerged during the analysis of the academics and industry personnel interviews that led to the compilation of overall perceptions that was the focus of this research. After the themes were carefully analysed it was evident that education for sustainability was a long-drawn out process for the vocational education sector in New Zealand. There was little conformity and collaboration between industry and academia on the subject of sustainability. Neither academics nor industry took responsibility of educating about sustainability but they did agree on a number of issues which are discussed further in the following section.

\section{Relevance of Sustainability}

The most notable finding on this research was that Academics and Industry personnel saw no relevance of sustainability in vocational trade education. They all felt that trade skills were distinctively separate to social skills like sustainability. One academic said: 
It's not for certificate students to deal with these issues [sustainability] but the management. It's no good being sustainable here (trade studies) but it's much more a global thing.

This suggests that academics were unaware of the importance of sustainability in the future and did not consider it important enough to warrant action. This mainly could be a result of lack of knowledge on the concept or reluctance to bring about change. Thomas (2004) states that academics fail to implement sustainability concepts into their courses because they have limited knowledge about it and fail to understand the importance of their engagement. The fact that the researcher had to explain about the concept of sustainability to some academics proves that many are unaware of the concept themselves thus will not be able to implement these concepts into their courses. Reid and Petocz (2006) mentioned a similar point about university academics who do not understand concepts of sustainability thus are unable to see the relevance of it in their subjects.

Like academics, Industry personnel elaborated that sustainability was irrelevant to industry and current market needs. They highlighted that industry was there to provide a service and meet the needs of the market. The workforce has no expectation from students to have knowledge about sustainability. Sustainability, according to industry, has no financial benefit and will not provide any immediate payback.

... a lot of people out there are just worried about the dollars. If they can't see an instant payment back and offers to people to make processes more economical in the long run, they are only worried about what the product will cost today.

This reflects the views expressed by Sterling (2001) who identified direct economic prosperity to be dominating the education and trades sector. However short-term economic gains are overshadowing long-term sustainable development. To what extent these shortterm gains will shape our future is questionable. Since industry has yet not realised the importance and significance of sustainability in all levels of trades and the workforce there has been no demand placed on an educational curriculum to reflect the concept.

With academics and industry personnel both agreeing on the irrelevance of sustainability in certificate and vocational education it appears that sustainability may not be well received in the educational arena in the near future.

\section{Responsibility of Education for Sustainability}

Academics and industry alike did not see their role in curriculum design at polytechnics. Academics said that they only teach skills that are required in the industry and sustainability is not a demand. They suggested that industry is unreceptive to sustainability and had not recognised it as being an important concept. They mentioned that since there was no demand placed on academics by industry to teach about sustainability hence it has not been implemented.

So in short no there is no expectation from industry that certificate graduates have awareness of sustainability issues. 
I think industry does not see it as their task to educate people about a concept that is not relevant to trades. They do not see themselves as educators in literacy or sustainability.

This indicates that academics only elaborate on concepts at certificate and vocational education that they feel can better equip a student to practice in the industry. Academics kept elaborating that they teach what industry demands but industry personnel refused to take any responsibility of the curricula. Industry Personnel commented that they need just basic grounding from students and everything else that is taught is the polytechnics initiative.

.... the board would say we just want a basic grounding and everything else they get on top is up to the person to receive on the job or through the polytechs.

This research showed that industry was very unsupportive of sustainability and therefore a change in curriculum to reflect the concept will be a very complicated process. The similarity in opinion between academics and industry personnel and their refusal to have any control of the curriculum seems to be the drawback of incorporating sustainability in the current vocational education sector.

\section{Sustainability Awareness}

On the positive note the industry personnel and academics did agree that awareness about the concept of sustainability would promote greater acceptance of the concept by everyone in the country. However with the negative attitude of the industry towards sustainability that has been highlighted by the research, prompts the thought whether the industry should be the first place where awareness needs to be increased. The denial of sustainability is indicated by comments made by one industry personnel who said:

The people who supply materials or produce it or manufacture, those are the sectors that where sustainability should be preached to and focused on.

Those academics that are aware about concepts of sustainability do make efforts to engage students with the concept. They did this purely because they were aware of the concept and highlighted the significance of sustainability whenever it was appropriate.

In the process of practical work we inform students about small practices we can use in form of mini lecture sessions where we tell students better work practices and sustainable practices.

This indicates that academics will definitely embed concepts of sustainability into their course if they are aware of it. Down (2006) suggested that motivating educators to understand and accept sustainability principles is the key factor in sustainability implementation in the curricula. This highlights the fact that if academics are aware about the concept of sustainability and shown the relevance of it in their courses they are more likely to teach it. 


\section{Conclusion-The Path Forward: Collaboration \& Professional Development}

It is evident through the research findings that education for sustainability has not being as readily accepted in vocational and trade education compared to other education sectors. There is immense negativity towards EfS from both industry and academics. Since there is no collaboration between industry and academics on EfS, the concept is being neglected from the vocational education system. Neither industry nor academics take responsibility of implementing or suggesting changes in the curriculum and this lack of collaboration is the biggest drawback for EfS. There also seems to be lack of awareness about sustainability among these two groups which is indicated on the combined view of sustainability being irrelevant for vocational trades. For the successful implementation of sustainability concepts stringent measures need to be taken to properly inform academics and industry about EfS. Once the awareness level increases among these two groups it will encourage greater collaboration towards implementing curriculum changes to reflect EfS.

\section{'Train the Trainer' Programme}

For sustainability to be integrated in all courses delivered at polytechnics a 'train the trainer' professional development (PD) programme is recommended that should be designed for academics which informs and educates them about the basics of sustainability and how the concept can be embedded into the academics' area of expertise. This course could be part of academics professional development plan. 'Changing teacher education' is also a recommendation made by Sterling (2001) who says that majority of teachers have no idea about how to teach sustainability and thus a in-service training could be an immediate solution to deal with this issue. Holdsworth, Wyborn, Bekessy and Thomas (2007) indicate that PD is important as it provides academics to sustainability concepts and provides them with capacity to implement curriculum change. Professional development has not been given priority in the higher education arena in many countries and New Zealand is no exception. Holdsworth etal., (2007) looked at professional development for education for sustainability in Australian universities and discovered that only one university offered a PD course designed to introduce academics to sustainability and teaching sustainability. Therefore for successful implementation of sustainability concepts into vocational trade curriculum it is vital to encourage professional development for all academics.

\section{Increase Awareness in Industry}

Education for sustainability should also be directed at industry and actions should be taken to increase awareness of sustainability in industry. Industry may be in denial about their influence on curriculum but their contribution towards sustainability education is reflected in the current education system. 


\section{References}

Cohen, L., Manion, L and Morrison, K. (2007). Research Methods in Education (sixth edition). Great Britain: TJ International Ltd.

Creswell, J. (2007). Qualitative Inquiry and Research Design: Choosing Among Five Approaches. Second Edition. USA: Sage Publications, Inc.

Down, L. (2006) Addressing the challenges of mainstreaming education for sustainable development in higher education. International Journal of Sustainability in Higher Education 7(4): 390399.

Fereday, J., \& Muir-Cochrane, E. (2006). Demonstrating rigor using thematic analysis: A hybrid approach of inductive and deductive coding and theme development. International Journal of Qualitative Methods, 5(1), Article 7. Retrieved 5 March 2007 from http://www.ualberta.ca/ iiqm/backissues $/ 5$ _ $1 / \mathrm{html} /$ fereday.htm

Fien, J. and Wilson, D. (2005). Promoting Sustainable Development in Tvet: the Bonn Declaration. Retrived on 31 October 2007 from http://www.ingentaconnect.com/content/klu/pros/2005/00000035/00000003/00004265

Holdsworth, S., Wyborn, C., Bekessy, S. and Thomas, I. (2007). Professional development for education for sustainability. How adavanced are Australian universities? International Journal of Sustainability in Higher Education. 9 (2), 131-146.

Johnson (n.d.). Chapter 12: Qualitative Research. Retrieved on 18 April 2007 from http://www.southalabama.edu/coe/bset/johnson/lectures/lec12.htm

Mazzoti, L., Murphy, B. and Kent, J. (2007). Finding the Common Ground: Is there a place for sustainability education in VET?: Support Document. Retrieved 31 October 2007 from http://www.ncver.edu.au/research/proj/nr4021.pdf

Ministry of Education. (2005). Profile and Trends: New Zealand 's tertiary Education Sector. Retievde 24 August 2007 from http://www.educationcounts.govt.nz/_data/assets/pdf_file/0017/9242/PT05-Part1.pdf

Moore, J. (2005). Is Higher Education Ready for Transfromative Learning?: A Question Explored in the Study of Sustainability. Journal of Transformative Education. 3 (1), 76-91.

Parliamentary Commissioner for the Environment (PCE). (2004). See Change : Learning and Education for Sustainability. Wellington: PCE, ISBN 1-877274-12-7, pp 37-67

Reid, A. and Petocz, P. (2006). University Lecturer's Understanding of Sustainability. Higher Education; 51 (1), 105-123. Retrieved 12 February 2007 from EBSCO Research Databases.

Schianetz, K., Kavanagh, L. and Lockington, D. (2007). Concepts and Tools for Comprehensive Sustainability Assessments for Tourism Destinations: A Comparative Review. Journal of Sustainable Tourism, 15 (4), 369-389. Retrieved 12 June 2009 from EBSCO Research Databases.

Somerville, M. (2003). The Nitty Gritty of Analysis: Analysing a Body of Qualitative Data. Unitec Workshop, Auckland. New Zealand.

Srinivas, H. (n.d.). Sustainable Development Concepts. Retrieved 12 June 2009 from http://www.gdrc.org/sustdev/concepts.html

Sterling, S. (2001). Sustainable Education: Re-visioning Learning and Change. Green Books Ltd, UK: ISBN 1-870098-99-4

Stone, L. and Baldoni, M. (2006). The Progress and Pitfalls in the Provision of Tertiary Education for Sustainable Development in New Zealand. Retrieved on 24 August 2007 from http://www.pce.govt.nz/projects/tertiary.pdf

Thomas, I and Nicita, J. (2002). Sustainability Education and Austrlian Universities. Environmental Education Research, 8 (4), 475-492. 
Thomas, I. (2004). Sustainability in Tertiary Curricula: What is stopping it happening? International Journal of Sustainability in Higher Education, 5 (1), 33-47. Retrieved 9 February 2006 from EBSCO Research Databases.

UNDESA. (1992). Agenda 21: Promoting Education, Public Awareness and Training. Retrieved 14 May 2006 from http://www.un.org/esa/sustdev/documents/agenda21/english/agenda21 chapter36.htm

United Nations. (2002). Plan of Implementation of the World Summit on Sustainable Development. Retrieved on 27 June 2007 from http://www.un.org/esa/sustdev/documents/WSSD_POI_PD/English/WSSD_PlanImpl.pdf

Wright, J. (2003). Introducing Sustainability into the Architecture Curriculum in the United States. International Journal of Sustainability in Higher Education; 4 (2), 100-105.

\begin{abstract}
About the Author
Rashika Sharma

Rashika is a lecturer in Integrated Practice at UNITEC New Zealand specialising in sustainable practice, societal context and generic skills on the Bachelor of Applied Technology. Rashika's research focus is on education for sustainability and takes keen interest in student centred teaching and learning strategies. Rashika has also taught at the Fiji Institute of Technology in Suva, Fiji.
\end{abstract}




\section{THE INTERNATIONAL C Environmental, Cultural, Economic \& Social

\section{Editors}

Amareswar Galla, The University of Queensland, Brisbane, Australia.

Bill Cope, University of Illinois at Urbana-Champaign, USA.

\section{Editorial Advisory Board}

Shamsul Nahar Abdullah, University of Malaysia Terengganu, Malaysia.

Wan Izatul Asma, University of Malaysia Terengganu, Malaysia.

Dang Van Bai, Ministry of Culture and Information, Vietnam.

Michael Cameron, University of Waikato, Hamilton, New Zealand.

Richard M. Clugston, University Leaders for a Sustainable Future, Washington, USA. John Dryzek, Australian National University, Canberra, Australia.

Dato'Abdul Razak Dzulkifli, Universiti Sains Malaysia, Malaysia.

Robyn Eckersley, University of Melbourne, Melbourne, Australia.

Steven Engelsman, Rijksmuseum voor Volkenkunde, Leiden, The Netherlands.

John Fien, RMIT University, Melbourne, Australia.

Suzanne Grant, University of Waikato, Hamilton, New Zealand.

Steve Hamnett, University of South Australia, Adelaide, Australia.

Paul James, RMIT University, Melbourne, Australia.

Mary Kalantzis, University of Illinois, Urbana-Champaign, USA.

Nik Fuad Nik Mohd Kamil, University of Malaysia Terengganu, Malaysia.

Lily Kong, National University of Singapore, Singapore.

Thangavelu Vasantha Kumaran, University of Madras, Chennai, India.

Jim McAllister, Central Queensland University, Rockhamptom, Australia.

Nik Hashim Nik Mustapha, University of Malaysia Terengganu, Malaysia.

Helena Norberg-Hodge, The International Society for Ecology and Culture (ISEC), UK.

Peter Phipps, RMIT University, Melbourne, Australia.

Koteswara Prasad, University of Madras, Chennai, India.

Behzad Sodagar, University of Lincoln, Brayford Pool, United Kingdom.

Judy Spokes, Cultural Development Network, Melbourne, Australia.

Manfred Steger, Illinois State University, Normal, USA; RMIT University, Melbourne, Australia.

Douglas Worts, LEAD Fellow (Leadership for Environment and Development), Toronto, Canada

David Wood, University of Waterloo, Waterloo, Canada.

Lyuba Zarsky, RMIT University, Melbourne, Australia; Tufts University, Medford, USA.

Please visit the Journal website at http://www.Sustainability-Journal.com for further information about the Journal or to subscribe. 


\section{The Sustainability Community}

This is a knowledge community brought together by a common concern for sustainability in an holistic perspective, where environmental, cultural, economic and social concerns intersect. The community interacts through an innovative, annual face-to-face conference, as well as year-round virtual relationships in a weblog, peer reviewed journal and book imprint - exploring the affordances of the new digital media. Members of this knowledge community include academics, researchers, policy makers, public servants, members of government and non-government organisations, consultants, educators and research students.

\section{Conference}

Members of the Sustainability Community meet at the International Conference on Environmental, Cultural, Economic and Social Sustainability, held annually in different locations around the world.

The Conference was held at the University of Waikato, Hamilton, New Zealand in 2011; University of Cuenca, Cuenca, Ecuador in 2010; University of Technology Mauritius, Mauritius in 2009; Universiti Malaysia Terengganu, Kuala Terengganu, Malaysia in 2008; University of Madras, Chennai, India in 2007; Hanoi and Ha Long Bay, Vietnam in 2006; and the University of Hawai'i at Manoa, Island of Oahu, Hawai'i, USA in 2005. In 2012, the Conference will be held at the Robson Square, University of British Columbia, Vancouver, Canada.

Our community members and first time attendees come from all corners of the globe. Intellectually, our interests span the breadth of the various sustainability disciplines and fields of study. The Conference is a site of critical reflection, both by leaders in the field and emerging scholars. Those unable to attend the Conference may opt for virtual participation in which community members can either submit a video and/or slide presentation with voice-over, or simply submit a paper for peer review and possible publication in the Journal.

Online presentations can be viewed on YouTube.

\section{Publishing}

The Sustainability Community enables members to publish through three media. First, by participating in the Sustainability Conference, community members can enter a world of journal publication unlike traditional academic publishing forums - a result of the responsive, non-hierarchical and constructive nature of the peer review process. The International Journal of Environmental, Cultural, Economic and Social Sustainability provides a framework for double-blind peer review, enabling authors to publish into an academic journal of the highest standard.

The second publication medium is through the book series On Sustainability, publishing cutting edge books in print and electronic formats. Publication proposals and manuscript submissions are welcome.

The third major publishing medium is our news blog, constantly publishing short news updates from the Sustainability Community, as well as major developments in the various disciplines of sustainability. You can also join this conversation at Facebook and Twitter or subscribe to our email Newsletter. 


\section{Common Ground Publishing Journals}

\begin{tabular}{|c|c|}
\hline $\begin{array}{l}\text { AGING } \\
\text { Aging and Society: An Interdisciplinary Journal } \\
\text { Website: http://AgingAndSociety.com/journal/ }\end{array}$ & $\begin{array}{c}\text { ARTS } \\
\text { The International Journal of the Arts in Society. } \\
\text { Website: www.Arts-Journal.com }\end{array}$ \\
\hline $\begin{array}{c}\text { BOOK } \\
\text { The International Journal of the Book } \\
\text { Website: www.Book-Journal.com }\end{array}$ & $\begin{array}{c}\text { CLIMATE CHANGE } \\
\text { The International Journal of Climate Change: } \\
\text { Impacts and Responses } \\
\text { Website: www.Climate-Journal.com }\end{array}$ \\
\hline $\begin{array}{c}\text { CONSTRUCTED ENVIRONMENT } \\
\text { The International Journal of the } \\
\text { Constructed Environment } \\
\text { Website: www.ConstructedEnvironment.com/journal }\end{array}$ & $\begin{array}{c}\text { DESIGN } \\
\text { Design Principles and Practices: } \\
\text { An International Journal } \\
\text { Website: www.Design-Journal.com }\end{array}$ \\
\hline $\begin{array}{c}\text { DIVERSITY } \\
\text { The International Journal of Diversity in } \\
\text { Organizations, Communities and Nations } \\
\text { Website: www.Diversity-Journal.com }\end{array}$ & $\begin{array}{l}\text { FOOD } \\
\text { Food Studies: An Interdisciplinary Journal } \\
\text { Website: http://Food-Studies.com/journal/ }\end{array}$ \\
\hline $\begin{array}{c}\text { GLOBAL STUDIES } \\
\text { The Global Studies Journal } \\
\text { Website: www.GlobalStudiesJournal.com }\end{array}$ & $\begin{array}{c}\text { HEALTH } \\
\text { The International Journal of Health, } \\
\text { Wellness and Society } \\
\text { Website: www.HealthandSociety.com/journal }\end{array}$ \\
\hline $\begin{array}{c}\text { HUMANITIES } \\
\text { The International Journal of the Humanities } \\
\text { Website: www. Humanities-Journal.com }\end{array}$ & $\begin{array}{c}\text { IMAGE } \\
\text { The International Journal of the Image } \\
\text { Website: www.Onthelmage.com/journal }\end{array}$ \\
\hline $\begin{array}{l}\text { LEARNING } \\
\text { The International Journal of Learning. } \\
\text { Website: www.Learning-Journal.com }\end{array}$ & $\begin{array}{c}\text { MANAGEMENT } \\
\text { The International Journal of Knowledge, } \\
\text { Culture and Change Management. } \\
\text { Website: www.Management-Journal.com }\end{array}$ \\
\hline $\begin{array}{c}\text { MUSEUM } \\
\text { The International Journal of the Inclusive Museum } \\
\text { Website: www.Museum-Journal.com }\end{array}$ & $\begin{array}{c}\text { RELIGION AND SPIRITUALITY } \\
\text { The International Journal of Religion and } \\
\text { Spirituality in Society } \\
\text { Website: www.Religion-Journal.com }\end{array}$ \\
\hline $\begin{array}{c}\text { SCIENCE IN SOCIETY } \\
\text { The International Journal of Science in Society } \\
\text { Website: www.ScienceinSocietyJournal.com }\end{array}$ & $\begin{array}{c}\text { SOCIAL SCIENCES } \\
\text { The International Journal of Interdisciplinary } \\
\text { Social Sciences } \\
\text { Website: www.SocialSciences-Journal.com }\end{array}$ \\
\hline $\begin{array}{c}\text { SPACES AND FLOWS } \\
\text { Spaces and Flows: An International Journal of } \\
\text { Urban and ExtraUrban Studies } \\
\text { Website: www.SpacesJournal.com }\end{array}$ & $\begin{array}{c}\text { SPORT AND SOCIETY } \\
\text { The International Journal of Sport and Society } \\
\text { Website: www.sportandsociety.com/journal }\end{array}$ \\
\hline $\begin{array}{c}\text { SUSTAINABILITY } \\
\text { The International Journal of Environmental, Cultural, } \\
\text { Economic and Social Sustainability } \\
\text { Website: www.Sustainability-Journal.com }\end{array}$ & $\begin{array}{c}\text { TECHNOLOGY } \\
\text { The International Journal of Technology, } \\
\text { Knowledge and Society } \\
\text { Website: www.Technology-Journal.com }\end{array}$ \\
\hline $\begin{array}{c}\text { UBIQUITOUS LEARNING } \\
\text { Ubiquitous Learning: An International Journal } \\
\text { Website: www.ubi-learn.com/journal/ }\end{array}$ & $\begin{array}{l}\text { UNIVERSITIES } \\
\text { Journal of the World Universities Forum } \\
\text { Website: www.Universities-Journal.com }\end{array}$ \\
\hline
\end{tabular}

